\title{
The Politics Of Corruption Eradication Law In The Aspect Of Anti- Corruption Education
}

\author{
Yunus Rahendra*) and Aryani Witasari**) \\ *) Military Academy Law Officer of Indonesia, E-mail:yunusrahendra@yahoo.com \\ ${ }^{* *}$ Faculty of Law Universitas Islam Sultan Agung
}

\begin{abstract}
The purpose of this study is to explain the need for aspects of anti-corruption education provided in educational institutions. Currently, the government is still focused on the regulation of legislation, especially on efforts to strengthen law enforcement. However, efforts to eradicate corruption by breaking the chain of its emergence by providing anticorruption education in educational institutions are a promising step if implemented optimally. Based on the above background, problems arise, namely how is the urgency of anti-corruption education, then how is the role of the government in anti-corruption education management. The research approach method used is normative juridical using secondary data. Data collection is done by collecting and analyzing library materials and related documents. Furthermore, the data from this study were analyzed qualitatively, namely by collecting research data to be processed which was then concluded to obtain information and answers to research problems. The conclusion of this research is the need for the role of the educational component to teach moral and ethical doctrine to students from an early age. In addition, the government's role is also important in supporting the implementation of anti-corruption education from the level of policy makers. Among them is the internalization of anti-corruption education in existing subject matter by updating the existing curriculum.
\end{abstract}

Keywords: Education; Anti-Corruption; Political Law; Education Management.

\section{Introduction}

The crime of corruption in Indonesia is a social problem that seems to never run out to be discussed. Corruption behavior occurs everywhere, both among relatives, in democratic and communist government systems, both in religious institutions, the phenomenon of corruption can occur. In almost every country, especially in the early days of government, the formation of a country corrupt behavior from state administrators and their cronies is rampant. The function of supervising each other among state institutions (checks and balances) has not run as it should. ${ }^{1}$ Corruption is an extraordinary crime that has deep roots in Indonesia. Corruption is seen as a serious crime because it has removed the economic and social rights of the community and can destroy the country's economy. Corruption is a threat to the principles of democracy, which upholds transparency, accountability, integrity, and security and stability of the Indonesian

\footnotetext{
${ }^{1}$ Hulman Siregar, Rumusan Pidana Dan Pemidanaan Tindak pidana Korupsi Yang Merugikan Keuangan Negara Serta Permasalaan Dalam Penerapannya, Jurnal Daulat Hukum Vol. 1. No. 1 Maret 2018, p. 126. (http://jurnal.unissula.ac.id/index.php/RH/article/view/2626.
} 
nation ${ }^{2}$ Corruption in Indonesia itself has become so severe due to the poor morality of officials in Indonesia. In terms of morality itself (Immanuel Kant 17241802) said that: "The highest the stars in the sky is still high morality in the human chest". ${ }^{3}$ This is because the superiority of humans compared to other creatures is a moral issue. However, if the moral has disappeared from human beings, then it can be said that humans are worse than other creatures.

Indonesia pays great attention to the eradication of corruption. The crime of corruption is seen as a serious crime because it is seen as a crime that interferes with the economic rights and social rights of the community and the state on a large scale, so that the handling must be carried out by means of extraordinary treatment, and the proof requires serious, professional and independent steps. ${ }^{4}$ Efforts to eradicate corruption have been intensified since the 1998 reformation with dissatisfaction with the handling of corruption. Therefore eradicating corruption became an important agenda in the 1998 reform at that time. However, until now, efforts to combat corruption are still an important concern of the government. How not, in 2010 the Transparency International Corruption Index (TICPI) managed to collect data that Indonesia is in the worst position in terms of corruption with a corruption achievement index of 2.4. The GPA scale starts from 1 to 10 , the greater the GPA value of a country, the cleaner the country is from acts of corruption. ${ }^{5}$ Corruption seems to have become a deeply rooted culture, especially in government agencies.

Facing this alarming phenomenon, it is necessary to take a step that needs to be taken by the government in determining policies in order to eradicate corruption, including by breaking the chain of corruption. Currently the government is focused on making efforts to overcome the problem of corruption by making improvements to law enforcement. Among the steps that have been taken is the discourse on the promulgation of the new KPK Bill, although it is still getting various responses in the community. There are still pros and cons to the discourse on the KPK Bill. Basically, what needs to be addressed in order to eradicate corruption apart from law enforcement is in terms of individual mentality, namely how to improve this mental corruption from an early age, namely since individuals receive education.

Legal politics is legal policy or official line (policy) of law that will be enforced either by making new laws or by replacing old laws, in order to achieve the goals of the state. ${ }^{6}$ The government's political policy in order to create a policy direction to tackle corruption is not only by crushing individuals who have sat and

\footnotetext{
2 Cindy Rizka Tirzani Koesoemo, eksistensi Komisi Pemberantasan Korupsi (kpk) dalam Penanganan Penyidikan dan Penuntutan Tindak Pidana Korupsi, Jurnal Lex Crimen Vol. VI/No. 1/Jan-Feb/2017, p.1. (https://www.neliti.com/id/publications/145840/existence-komisi-berantasan-korupsi-kpkdalam-handan-penyidikan-dan-penu\#id-section-content

${ }^{3}$ Mohamad Hidayat Muhtari, Model Politik Hukum Pemberantasan Korupsi di Indonesia Dalam Rangka Harmonisasi Lembaga Penegak Hukum, Jambura Law Review Vol. 1 Issue 01/ January 2019, p. 70-71. (https://ejurnal.ung.ac.id/index.php/jalrev/article/view/1988 accessed on 27 June 2021) ${ }^{4}$ Hernolad Ferry Makawimbang, Kerugian Keuangan Negara dalam Tindak Pidana Korupsi, Suatu Pendekatan Hukum Progresif, (Yogyakarta: Thafa Media), 2014, p. 1

${ }^{5}$ Agus Wibowo, Pendidikan Anti Korupsi di Sekolah, Strategi Internalisasi Pendidikan Antikorupsi di Sekolah,(Yogyakarta: Pustaka Pelajar, 2013), p. 1.

${ }_{6}^{6}$ Mahfud M.D., Politik Hukum di Indonesia, (Jakarta: Rajawali Pers, 2017), p. 1.
} 
stood behind the wheels of government that have been running, but can be done by carrying out individual mental revolutions since they were in education. Legal politics is an integral part of social policy (Social welfare policy) and public protection policy (social defense policy) in order to achieve certain goals (goals). Legal politics can also be said to be law enforcement politics in a broad sense, namely the cultivation of unlawful acts that may occur or that actually occur. ${ }^{7}$ Therefore, anti-corruption education that begins when an individual is in school becomes a part that needs to be encouraged by the government in the context of implementing legal politics to eradicate corruption from the mental aspect of the individual. The purpose of this study is to determine the urgency of anti-corruption education and the role of the government in the management of anti-corruption education.

\section{Research Methods}

Method The approach used in this paper is a qualitative approach, which aims to understand the condition of a context by leading to a detailed and in-depth description of the portrait of conditions in a natural context (natural setting), about what actually happened according to what was in the field of study. The type of legal research used is the type of normative legal research. The type of normative legal research is legal research conducted by examining library materials or secondary data. ${ }^{8}$ Writing This is descriptive analytical, intended to provide data that is as accurate as possible about humans, conditions or other symptoms, ${ }^{9}$ namely to get an overview and provide an explanation of the current state of corruption eradication in Indonesia and how the strategy is applied in the educational environment.

This research includes normative legal research, so the type of data used is secondary data. Secondary data in this study were obtained from books on corruption eradication and anti-corruption education, research journals on anticorruption education, to sources obtained from internet media related to the urgency of eradicating corruption. In accordance with the data source that uses secondary data in this study, the data collection method is carried out through literature study and document study by collecting and analyzing library materials and related documents.

\section{Result and Discussion}

\subsection{The Urgency of Anti-Corruption Education.}

Based on its origin, corruption comes from the Latin, namely corruptio or corruptus from the verb corrumpere which means rotten, damaged, destabilizes, distorts, bribes. From Latin down to many European languages such as English: corruption, corrupt; french: corruption; and Dutch: corruptie (korruptie). The Dutch language greatly influenced the origin of words in Indonesian which was then known as corruption. According to the Big Indonesian Dictionary, corruption

\footnotetext{
${ }^{7}$ Nyoman Serikat Putra Jaya, Politik Hukum, (Semarang: Badan Penerbit Diponegoro, 2016), p. 67. ${ }^{8}$ Soerjono Soekanto, Sri Mamudji, Penelitian Hukum Normatif, (Jakarta: Rajawali Pers,2012), p.13. ${ }^{9}$ Soerjono Soekanto, Pengantar Hukum Indonesia, (Jakarta:UI,2006), p.10.
} 
is the misappropriation or misuse of state money (companies and so on) for personal or other people's gain. ${ }^{10}$ Corruption from the origin of the word in this case is something in the form of decay and is carried out by twisting, bribing, damaging and destabilizing. From this term it can be interpreted that corruption is something that is done in various ways to achieve goals. In this act of corruption in a person, what is influential is his morals. School education has been more dominant in developing science and technology education (science and technology). So to realize anti-corruption education, school education must be oriented to moral action so that students do not just stop at competence, but to have the will and habits in realizing values in everyday life (Hujair AH. Sanaky, 2010). ${ }^{11}$

The estuary of the corruption problem is the loss of anti-corruption values (honest, caring, independent, disciplined, responsible, hard work, simple, courageous, fair) from within the individual. The world of education, which is expected to strengthen the anti-corruption culture, is increasingly felt to be inconsistent in carrying out its functions. The educational process is still concerned with mastering knowledge rather than getting used to good behavior. Therefore, at this time it is necessary to restore schools as a locomotive for strengthening anticorruption culture in the long term. ${ }^{12}$ As Lickona (1991) argues, that to educate children's morals to the level of moral action, three continuous development processes are needed, starting from the process of moral knowing, moral feeling, to moral action. ${ }^{13}$ According to Biyanto (2010), there are several reasons why it is important that anti-corruption education is immediately applied in schools to universities:

- The world of education, especially educational institutions in general, has a set of knowledge (knowledge), to shed light on various misunderstandings in the fight against corruption. Because until now the definition of corruption that is taught is only a legal-formal understanding. Meanwhile, various corrupt practices have flourished and taken root in the community. In a situation like this, educational institutions with available resources can be a reference to enlighten the problematics of corrupt practices.

- Educational institutions are important to be involved in eradicating corruption because they have strong networks throughout the country. The involvement of educational institutions from elementary, middle, to tertiary levels will be an effort to eradicate corruption, which can turn into a massive movement, so that with this massive movement, Indonesia can get out of the problem of corruption.

- If one examines the social background of the perpetrators of corruption, it can be said that the majority are college alumni. They usually have a bachelor's degree. So that socially the educational background is quite well established. But why are they breaking the law? Because apart from enriching themselves,

\footnotetext{
${ }^{10}$ Azis Min Alamsyah, Sudrajat, Apersepsi, Modus, dan Kasus Korupsi, (Bandung: CV Pustaka Setia, 2019), p. 2.

${ }^{11}$ Agus Wibowo, Op.cit., p. 40.

12 Aclc.kpk.go.id., Anti-Corruption Education., accessed 24 June 2021

${ }^{13}$ Agus Wibowo, Op.cit., p. 39
} 
they do not know the intricacies of criminal acts that are categorized as corruption. ${ }^{14}$

From this view, educational institutions can maximize their functions so that in the future they are able to provide a useful role in efforts to eradicate corruption. Eradication of corruption through educational institutions is a longterm investment. This is because what is given by educational institutions to individuals is not a justify or punishment as applied by law enforcers when eradicating corruptors who are more coercive and the result is deterrence. Anticorruption education here is taught by educators who teach moral and ethical doctrine, so this is a long-term investment. Therefore the results will not be seen in an instant.

\subsection{The Government's role in the management of anti-corruption education.}

Legal culture is one part of such a broad human culture. Legal culture is the same general response of certain people to legal phenomena. The response is a unified view of legal values and behavior. ${ }^{15}$ Thus, the purpose of internalizing anticorruption education in educational institutions is to create an anti-corruption culture for the younger generations who will later occupy strategic positions in running the government. The legal culture of the Indonesian people shows two opposing positions, on the one hand, declaring war on corruption, hating the actions of corruptors, and even condemning corruptors, but on the other hand, the public actually shows support for corruption. This support is shown by giving bribes to government officials and giving preferential treatment to bureaucrats. In recruiting employees in the government, there are still many people who are willing to pay some money to "insiders" in order to be accepted both as civil servants and as contract workers. ${ }^{16}$ Therefore, it is the mental culture of the law that needs to be improved in educational institutions.

Management of anti-corruption education in schools in short is education management that manages the internalization of anti-corruption education in schools to be effective. ${ }^{17}$ To be able to achieve effective education in the context of efforts to instill an anti-corruption legal culture, efforts are needed from all components of education which include the curriculum, students, the educators themselves, facilities and infrastructure, funds, environment, and teaching and learning activities. These components are focused on supporting the implementation of teaching and learning activities, in order to obtain outputs/graduates of students who have an anti-corruption legal culture. Therefore, the government has a role as a provider of legal policy directions that are implemented nationally to carry out the components of education.

\footnotetext{
${ }^{14}$ Ibid., p. 41-42.

${ }^{15}$ Musa Darwin Pane, Peran Budaya Hukum dalam Pembaharuan Sistem Hukum Pidana Perihal Efektifitas Penegakan Hukum Tindak Pidana Korupsi di indonesia, Majalah Ilmiah bidang hukum Vol. 16 No. 1, p. 67. (https://jurnal.unikom.ac.id/jurnal/peran-biudaya-law-dalam.

${ }^{16} \mathrm{Ni}$ Luh Gede Yogi Arthani, Budaya Hukum dalam Pemberantasan Tindak Pidana Korupsi, Jurnal Budaya Hukum, p.189. (https://jurnal.unmas.ac.id/index.php/advocation/article/download/714/665.

${ }^{17}$ Agus Wibowo, Op.cit., p. 176.
} 
Regarding government policies in the context of instilling an anticorruption culture, the Minister of Research, Technology and Higher Education Mohamad Nasir and the Chairman of the KPK Agus Rahardjo made a commitment to implement anti-corruption education at the elementary, secondary and higher education levels on December 11, 2018 through a Press Release Number: 338/SP/HM/BKKP /XII/2018. ${ }^{18}$ This step is a positive breakthrough in order to start implementing a learning system that internalizes anti-corruption values in educational institutions.

In line with this, education management has several functions in carrying out the internalization of an anti-corruption culture. Among these functions are planning, organizing, implementation (motivation, leadership, decision making, communication and coordination), as well as supervision and control. ${ }^{19}$ This function needs to be coordinated or managed by the government, especially in this case the ministry of education, so that it can be used as a curriculum or an addition to the existing education system. Thus, nationally, anti-corruption education has become a permanent curriculum for educational institutions because it has been included as part of the curriculum. For elementary to secondary school levels, anticorruption education can be included in civic education materials, for example, while for higher education levels it can be included in General Basic Courses (MKDU).

Eradication of corruption needs to be supported by a strong national legal construction so that on the one hand it can maintain the character of the Unitary State of the Republic of Indonesia (NKRI) and on the other hand out of the box efforts can be carried out with the latest creativity for eradicating corruption. ${ }^{20}$ Corruption in Indonesia is no longer a new case but has become one of the most popular cases of abuse of power and has spread to various aspects of Indonesian people's lives. Facing this alarming reality, the Government's consistency is needed in overcoming and preventing corruption, which must be carried out in a real and comprehensive manner ${ }^{21}$ in the eradication process in Indonesia. For this reason, it is necessary for the government's role in "supporting" national educational institutions to instill an anti-corruption culture from an early age to today's young generation.

Anti-corruption education for the next generation can be a very important glimmer of hope to be prepared for a brighter tomorrow. A great nation is a nation that is known for its character which can be a good example for other nations. The Indonesian nation, which is currently one of the countries that has the highest level of corruption in the world, can move in a better direction with the birth of

\footnotetext{
${ }^{18}$ https://www.ristekdikti.go.id/kabar/Pendidikan-anti-korupsi-akan-applied-di-all-jenjangPendidikan-2/ dated 03 July 2020.

${ }^{19}$ Agus Wibowo, Op.cit., p. 175.

${ }^{20}$ Arfan Faiz Muhlizi, Revolusi Mental untuk Membentuk Budaya Hukum Anti Korupsi, Jurnal RechtsVinding, Media Pembinaan Hukum Nasional, Volume 3 Nomor 3, Desember 2014, p. 453. (https://rechtsvinding.bphn.go.id/ejournal/index.php/jrv/article/view/36/0 accessed on 15 July 2021)

${ }^{21}$ Nur M. Kasim, Politik Hukum Pemberantasan Tindak Pidana Korupsi di Indonesia, Jurnal Inovasi Vol. 9, Nov. 2, June 2012, p. 2. (http://ejurnal.ung.ac.id/index.php/JIN/article/view/829 accessed on June 25,2021 )
} 
generations who have an anti-corruption mentality. With an anti-corruption mentality embedded in the next generation, it is not impossible that the Indonesian people will be known by other nations as a nation that has anti-corruption characters so that the country becomes a developed country.

\section{Closing}

The definition of corruption that is taught in schools today is only a legalformal understanding, while various corrupt practices have flourished and taken root in the community. In a situation like this, educational institutions with available resources can be a reference to enlighten the problematics of corrupt practices through basic education in schools. Therefore, the involvement of educational institutions from elementary, middle, to tertiary levels will be an effort to eradicate corruption that can transform into a massive movement, so that it can become hope in the future to overcome the problem of corruption in Indonesia. These components are focused on supporting the implementation of teaching and learning activities, in order to obtain outputs/graduates of students who have an anti-corruption legal culture. Therefore, the government has a role as a provider of legal policy directions that are implemented nationally to carry out the components of education. This role includes the internalization of anti-corruption cultural values that can be included in the education curriculum. The internalization of anti-corruption education can be carried out starting from planning, organizing, implementing (motivation, leadership, decision making, communication and coordination), as well as supervision and control.

\section{References}

\section{Journal}

[1] Arthani, Ni Luh Gede Yogi. Budaya Hukum dalam Pemberantasan Tindak Pidana Korupsi (Jurnal Budaya Hukum). 2016. .(https://jurnal.unmas.ac.id/index.php/advokasi/article/download/714/66 5).

[2] https://www.ristekdikti.go.id/kabar/pendidikan-anti-korupsi-akanditerapkan-di-semua-jenjang-pendidikan-2/

[3] Kasim, Nur M. Politik Hukum Pemberantasan Tindak Pidana Korupsi di Indonesia. (Jurnal Inovasi Vo. 9, Nov. 2). June 2012. (http://ejurnal.ung.ac.id/index.php/JIN/article/view/829)

[4] Koesoemo, Cindy Rizka Tirzani. eksistensi Komisi Pemberantasan Korupsi (kpk) dalam Penanganan Penyidikan dan Penuntutan Tindak Pidana Korupsi. (Jurnal Lex Crimen Vol. VI/No. 1) Jan-Feb 2017. (https://www.neliti.com/id/publications/145840/eksistensi-komisipemberantasan-korupsi-kpk-dalam-penanganan-penyidikan-dan-penu\#idsection-content)

[5] Muhlizi, Arfan Faiz. Revolusi Mental untuk Membentuk Budaya Hukum Anti Korupsi (Jurnal RechtsVinding,Media Pembinaan Hukum Nasional Volume 3 Nomor 3. Desember 2014. 
(https://rechtsvinding.bphn.go.id/ejournal/index.php/jrv/article/view/36/ $0)$.

[6] Muhtari, Mohamad Hidayat. Model Politik Hukum Pemberantasan Korupsi di Indonesia Dalam Rangka Harmonisasi Lembaga Penegak Hukum. (Jambura Law Review Vol. 1 Issue 01/). January 2019 (https://ejurnal.ung.ac.id/index.php/jalrev/article/view/1988.

[7] Pane, Musa Darwin. Peran Budaya Hukum dalam Pembaharuan Sistem Hukum Pidana Perihal Efektifitas Penegakan Hukum Tindak Pidana Korupsi di indonesia (Majalah Ilmiah bidang hukum Vol. 16 No. 1) (https://jurnal.unikom.ac.id/jurnal/peran-biudaya-hukum-dalam.

[8] Siregar, Hulman. Rumusan Pidana Dan Pemidanaan Tindak pidana Korupsi Yang Merugikan Keuangan Negara Serta Permasalaan Dalam Penerapannya. Jurnal Daulat Hukum Vol. 1. No. 1.2018. (http://jurnal.unissula.ac.id/index.php/RH/article/view/2626)

\section{Book}

[1] Alamsyah, Azis Min. Sudrajat. 2019. Apersepsi, Modus, dan Kasus Korupsi. Bandung: CV Pustaka Setia.

[2] Jaya, Nyoman Serikat Putra. 2016. Politik Hukum. Semarang: Badan Penerbit Diponegoro.

[3] Makawimbang, Hernolad Ferry. 2014. Kerugian Keuangan Negara dalam Tindak Pidana Korupsi, Suatu Pendekatan Hukum Progresif. Yogyakarta: Thafa Media.

[4] M.D, Mahfud. 2017. Politik Hukum di Indonesia. Jakarta. Rajawali Pers.

[5] Soekanto, Soerjono, Sri Mamudji. 2012. Penelitian Hukum Normatif. Jakarta: Rajawali Pers.

[6] Soekanto, Soerjono. 2006. Pengantar Hukum Indonesia. Jakarta:UI.

[7] Wibowo, Agus. 2013. Pendidikan Anti Korupsi di Sekolah, Strategi Internalisasi Pendidikan Antikorupsi di Sekolah. Yogyakarta: Pustaka Pelajar. 